\title{
OS ÍCONES E SEUS SIGNOS: A APLICABILIDADE DAS IMAGENS NAS PESQUISAS E ESTUDO DA HISTÓRIA DO IMPÉRIO BIZANTINO
}

\author{
The icons and their signs: the applicability of the \\ images in the research and study of the History of the \\ Byzantine Empire
}

Paulo Augusto Tamanini*

\begin{abstract}
RESUMO
$\mathrm{O}$ estudo das imagens tende a circunstanciar informações que reverbera em um campo de abordagens multifacetado, aberto à estranheza da História. Quando o objeto em análise trata de um conjunto de ícones bizantinos, parece natural reportá-lo aos assuntos de Teologia, negando a possibilidade de a História também sobre ele arguir, discorrer e tecer seus pareceres. Contrariando esta tendência, este artigo aborda os ícones bizantinos em sua historicidade, em sua feitura estética e diálogo com a Teologia da Igreja Ortodoxa Oriental. Por receber influências dessas áreas do saber, a abordagem é pensada transdisciplinarmente, usando como ponto de partida o conceito de signo pensado por Gilles Deleuze. Quer igualmente contribuir em alguns pontos teóricos acerca do uso das imagens bizantinas na construção da narrativa historiográfica.
\end{abstract}

Palavras-chave: Iconografia Bizantina; História das Imagens; Gilles Deleuze; Iconologia Oriental e Religiosidades.

* Professor Pesquisador Bolsista PNPD-CAPES/PPGH-UFPR (2015-).Doutor em História pela UFSC (2013). Mestre em História pela UDESC (2010). Especialista em Teologia e

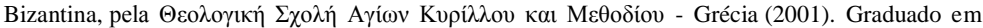
Filosofia pela UNIFEBE (1991). Suas pesquisas versam sobre o Império Bizantino; as Igrejas de Rito Bizantino: ortodoxas e católicas; iconofrafia e o uso das imagens na pesquisa historiográfica. 


\begin{abstract}
The study of religious image tends to give details information that reverberates in a field of multi-faceted approaches, open to the strangeness of history. When the object in question is a collection of Byzantine icons, it seems natural to report it to Theology issue, denying the possibility of also the story about him argue, discuss and weave their opinions. Contrary to this trend, this article discusses the Byzantine icons in its historicity, in its aesthetic making and dialogue with the theology of the Eastern Orthodox Church. To receive influences of these fields of knowledge, the approach is thought transdisciplinary, using as a starting point the concept of sign designed by Gilles Deleuze. Want to also contribute in some theoretical points about the use of images in the construction of Byzantine historiographical narrative.
\end{abstract}

Keywords: Byzantine Iconography; History of Images; Gilles Deleuze; Eastern Iconologia and Religiosities.

\title{
Introdução
}

$\mathrm{Na}$ perspectiva de Gilles Deleuze, o aprender é mediado pelos signos emitidos pela matéria ou objeto, abertos à decifração, decodificação, interpretação. Para o filósofo, enquanto o emissor de signos ensina, quem aprende é o intérprete, o decifrador (DELEUZE, 2003 , p. 4). Isto posto, é possível então inferir que os signos carregam mensagens sob véus, realidades implícitas, unidades subjetivadas de um realismo questionável pela racionalidade; por isso, ensinam, doutrinam, emitem saberes igualmente anuviados.

O ícone bizantino parece ser assim. Para além de ser um objeto material pensado a partir do século III para a projeção de poder e consolidação do pensamento estratégico de Bizâncio através das imagens, foi, desde o século IV, também um artifício que promoveu devoções cristãs e fez despertar práticas religiosas protocolares. Atualmente, os ícones bizantinos são também uma forma de arte que remete a um tempo em que o Império Romano no Oriente vivia seu apogeu. Uma vez captados pelos olhos da fé dos que ainda se crêem legatários desse patrimônio cultural, são capazes de emitir signos que 
necessitam ser decifrados por olhos e mentes treinados para poder significar.

No tempo presente, o sentido religioso derivado do ícone bizantino então é traduzido por sistemas de referências de quem percebe as imagens sacras como emitentes de signos, possuidoras de potencialidades de transmissão de conhecimentos de natureza mística. Via de mão dupla, signo e decodificação embrulham o composto imagético em um caminho que tanto oferece quanto retira códigos de intelecção e de crenças. Portadora de signos abertos, a porção figurativa dos ícones bizantinos não fica alheia a transformar ambientes e entendimentos sobre realidades intangíveis unicamente pela razão. Porque imitem signos críveis, produzem deslocamentos de significados entre o receptor e o emitente que resenham fluxos de compreensão. Decorrente disso, as imagens têm tarefa infindável no ato de representar à medida que também são duradouros e intermitentes os critérios de observação. No tocante às imagens bizantinas, sem cair em transgressões e rupturas de limites, o ícone religioso, de modo geral, convida-se sem credenciais a irromper barreiras e se imiscui em oportunidades dedutivas sobre quem a contempla. Uma vez captados e decodificados, os signos emitidos pelos ícones descansam em uma inteligibilidade promotora de outas apreensões cognitivas: as de cunho religioso.

A imagem bizantina como materialidade de um saber testado pelo tempo e pelos pensadores, representa para a História também uma fonte eivada de códigos que esconde dizeres. Ela não é apenas a representação da genialidade de um artista ou a prova inconteste da competência de um monge do Medievo que, com maestria soube roubar do tempo os instantes que eram só dele. O bizantinismo imagético constitui-se então, manancial de aprendizagem, porque os signos emitidos por ele anunciam um modo de pensar a cultura de modo mais circunspecto. Longe de serem lidas e colocadas sob a égide das hermenêuticas de cada um, em um processo de subjetivação cheia de particularismos, as fontes imagéticas do período bizantino garimpadas do deslumbre da arte, explicitam hoje para a Historiografia novos desafios e que abrem perspectivas de investigação múltiplas para a apreensão o Medievo.

As imagens bizantinas de cunho religioso também são fontes das quais a História se interessa para a construção de uma narrativa, 
uma vez que os ícones não se restringem apenas a informar, anunciar e dizer uma fé instituída. Os conhecimentos transmitidos a partir deles, se por um lado brotam da introspecção, remetendo ao transcendente, ao místico, do outro, oportuniza o pesquisador ao desafio de esmiuçar modos de vivência, pensamentos que norteavam um grupo social, mentalidades que repercutiam em atitudes coletivas, modos de percepção do mundo, organizações, estruturas e hierarquias na vida da corte imperial. O ícone não diz somente sobre as coisas de Deus, mas sobre as coisas dos homens e suas instituições.

Aos olhos de grupos imigrantes de cristãos orientais que aportaram no Brasil desde o século XVIII e herdeiros do patrimônio bizantino grego e eslavo ${ }^{1}$ por exemplo, a imagem iconográfica parecia ser suficiente para justificar uma crença, parecendo não necessitar de intérpretes, de hermeneutas pois gritava a todos um modo de crer gestado por um tempo e cultura específicos. Contudo, as formas, as cores, os vocábulos fantasiados de tinta e misticismos mais do que isso, escreveram o formal modo de percepção, inspiraram relatos, provocaram narrativas, emitiram signos passíveis de deduções que ultrapassaram a natureza religiosa. Transportaram signos que, atualmente podem auxiliar o pesquisador a novos insights, não só acerca de temas familiares às religiosidades como também aos de natureza relacional, orgânicas e de mentalidades.

A Historiografia que trata das imagens do período Bizantino parece ser também devedora de uma compreensão mais alargada acerca dos signos emitidos pelas imagens sacras ou religiosas, já que elas, vez por outra, recorrem a métodos decifratórios alijados da pura razoabilidade. Antes de tudo, o ícone bizantino é fonte materializada que diz muito sobre um tempo da História em que conceitos, valores e mentalidades estavam associados à crença da interferência do divino na vida prática do Império Romano no Oriente. Por isso, sem atrelar alguns conhecimentos da Teologia Bizantina com a História, fica despropositada a decodificação precisa dos signos que as imagens iconográficas possam sugerir. Ainda que os profissionais do passado

1 Grupos de imigrantes ucranianos, russos, antioquinos, poloneses, gregos chegados ao Brasil com a Grande Imigração e que formaram pequenas comunidades étnico-religiosas nas regiões Sul e Sudeste do país. 
continuem interconectando dizeres, fazendo apologias, refletindo sobre a interferência da imagem bizantina na escritura de narrativas, sem uma comunhão teórica do período patrístico oriental ${ }^{2}$, sentir-se-ia inábil de apreender os ícones em muitas de suas especificidades. Por ser a imagem iconográfica bizantina um texto -como todas as outras são!- necessita ser lida e passar pelo crivo das acareações, sugestionamentos teóricos e interpretações aceitáveis. Carregada pela mística ou pela razoabilidade é um escrito que cientifica pensamentos e inteira a natureza da escrita e pesquisa da História.

Sendo emitente de signos e ao mesmo tempo receptáculo das emoções, toda imagem para a Historiografia institui-se texto aberto, alternando com o historiador os momentos de criação e de destruição das certezas graças aos efeitos imediatos de leitura. Nessa incompletude, o pesquisador das imagens cristãs bizantinas por mais que se esforce para tirar delas o que acredita ser mera interpretação, fruto de suas subjetividades, terá a sensação de lhe faltar algo, pois o ícone não se deixa revelar em sua inteireza. Parece fazer parte de sua natureza um magnetismo proveniente da sedução do velamento. Logo, o ícone bizantino não se deixa cultuar como fazem a de Vênus (Botticelli, 1486), a de Gioconda (Da Vinci, 1517), a de Dr. Gachet (Van Gogh, 1890), a de As Meninas (Vellasquez, 1656), a da Leiteira (Vermeer, 1658) etc., quer apenas ser apreendido por olhos transfigurados. Olhos cujos donos ultrapassem os limites da racionalidade para impor uma transubstanciação dos signos que se entrega à sensibilidade estético-religiosa que a iconografia cristã oriental tenta prezar desde o século IV.

A partir do foco aproximado das experiências e subjetividades humanas e do pensamento deleuziano acerca do signo, este artigo busca circunstanciar a aplicabilidade das imagens, mas especificamente as da iconografia bizantina, no campo de estudos e pesquisas da História. Pretende-se então demonstrar algumas possibilidades de se compreender os fenômenos humanos em relação

2 Gregório Palamás, Basílio, João Crisóstomo, Inácio de Antioquia, João Damasceno, Gregório de Nissa, Eusébio de Cesaréia são algumas referências sobre o estudo da imagem na construção da fé cristã. 
ao sagrado, a partir de reformulações dos postulados teóricos acerca das imagens compreendidas como fontes de pesquisa.

Além desta conformidade, torna-se fundamental lembrar que, ainda que se utilize de autores que tratam em suas pesquisas da análise das imagens, as teorias e métodos usados para compor um saber iconográfico devem estar atentos aos da própria Teologia Cristã. Sem um conhecimento prévio dessa Teologia, o estudo das imagens iconográficas estaria incompleto, uma vez que os ícones nascem do conhecimento teológico do cristianismo oriental. Não se trata de substituir um conhecimento pelo outro, mas se servir, quando possível, de uma abordagem teórico-metodológica para a elaboração de narrativas abertas, multidisciplinares e associativas.

\section{A Iconografia cristã Oriental e o século IX: a legitimação da imagem como signo e artefato de fé}

A igreja cristã, para além de toda auréola mística que a envolve, é também uma instituição enraizada em espaços, onde se produz historicamente. E, por também ser portadora de capital simbólico e detentora de monopólio religioso, oferta valores produzidos pelo sistema que criou. Assenhorando-se ou produzindo capital imagético sacro, ao longo dos séculos, traçou-lhe contornos de identificação conforme os lugares de sua gênese ou posterior estruturação. Assim, as pequenas comunidades cristãs nascidas no Oriente, ganhando a proteção e o incentivo dos poderes temporais, multiplicavam-se em número e em diversos espaços tanto quanto os pressupostos que justificavam sua existência. Ainda que ideologias e discursos mundanos, força e poder fizessem parte de algumas de suas preocupações ordinárias, o prestígio e a força de representação por possuir algo de transcendente não saíam de seu encalço, viabilizando novas conquistas, outros territórios e espaços (SAID, 2007).

Motivadas pelo fervor inicial, as Igrejas cristãs, graças às investidas missionárias dos primeiros adeptos e ao incentivo dos reinos levaram sua mensagem e doutrinação dos locais nascentes aos 
de língua hebraica e grega. Nos três primeiros séculos, ainda que pesasse as perseguições, o cristianismo se espalhava pelo Oriente e, à medida que foi aceito como religião instituída do Império Romano, estruturava-se e construía uma escala hierárquica, deixando pelo caminho as marcas de um percurso organizativo e de sua relação com o mundo bizantino.

O nome Oriente criado, inventado para designar a porção de espaço geográfico, é também fruto de influências culturais, de pensamento e modos de agir. Não sendo ele bloco homogêneo dentro do qual tudo se assemelha, é possível verificar que o Oriente, tido por Hegel como o "lugar onde começa a vida e aonde o sol nasce" (HEGEL, 1995, p. 194), nem sempre significou homogeneidade, ascensão e luz, como o oposto não era tributo exclusivo do Ocidente. Dessa maneira, a diferença, definidora de todo lugar, não é resultante de justaposições, mas de encaixes de realidades (CERTEAU, 2007), amalgamadas, ora por negociações, ora por convenções. No decurso da História do paleocristianismo, a imbricação entre a Igreja nascente e o Império Romano no Oriente legitimou o surgimento da necessidade de estruturas de governo para as pequenas comunidades de fé. Com os Editos de Milão (313 d.C.) e de Tessalônica (380 d.C.) se iniciava uma organização diferente no modo de se pertencer oficialmente à comunidade cristã.

Com erguimento de sedes e templos, financiados pelo Império, a gestão dos agentes religiosos cristãos ganhava uma referência no espaço bizantino, um endereçamento de onde se podia administrar, distribuir e investir os bens simbólicos daquela jurisdição cristã embrionária. Porque os primeiros episcopados cristãos instituíam-se - para além de um núcleo organizativo religioso - um centro administrativo e uma visível estruturação dos dispositivos de autoridade de seus líderes, podiam otimizar os projetos de missão locais, sem se esquecer dos mecanismos formais emitidos pelos chanceleres imperiais, tais como, a catalogação, os despachos e arquivamento de documentos devidamente protocolizados. Então, situadas em seus lugares de empoderamento, as primeiras sedes episcopais cristãs tinham um lugar de deferência de onde centralizavam o poder hierárquico e singularizavam o exercício da autoridade religiosa. As ações de mando e governança ganhavam 
legitimidade mapeadas dentro de um organograma hierárquico legitimado pelo império Romano e pelos Concílios Ecumênicos.

Uma vez credenciados a agirem em nome da Igreja e do Império, os primeiros sete Concílios Ecumênicos, convocados sempre pelos Imperadores, quais centros prontos para gestar, instituíam-se nascedouros de um modo de gerenciar o conteúdo de fé da Igreja sob a anuência de pares episcopais. Com a institucionalização conciliar, as comunidades cristãs bizantinas não estavam mais desendereçadas. Tinham um lugar formal de representatividade institucional sob o auspício imperial sobre o qual o tempo de perseguição e martírio não tinha mais poder de ressurreição. O escriturístico, decorrente dos documentos assinados e carimbados pelos bispos dos concílios e chancelados pelos imperadores, o representavam, assim como faziam as imagens.

Com a interferência imperial, as igrejas, uma vez construídas, eram decoradas segundo as tradições e pareceres litúrgicos dos costumes Orientais grego. Esse arquétipo organizacional litúrgico fez inaugurar não somente um novo modelo de religião para o Império, como também a forma de se manifestar uma fé ritualizada, compassada e oficiosa que deveria ser disseminada por toda sua jurisdição. Era uma luta contra o tempo. $O$ culto e crenças pagãs deveriam curvar-se à nova religião cristã; o que acarretava estratégia e tino mediático singulares. Era urgente que se buscasse na fé dos cristãos o que tinha de mais característico e de mais fascinante para que novos adeptos se somassem à nova religião sem grandes traumas. A pedra de toque foi explorar o uso das imagens cristãs como emitente de símbolos, signos, mistérios e fazer dessa devoção um marco de piedade aderido e legitimado, por primeiro, pela nobreza imperial e classes dominantes e, posteriormente, pelos demais (RIBICHINI, 2007, p. 43).

A Iconografia bizantina foi um modo de arte que eclodiu no início da Igreja para diferenciar do culto às estátuas dos deuses da mitologia grega e romana. Se as divindades eram representadas por imagens tridimensionais esculpidas em mármores, bronze, ouro ou pedra, as do cristianismo passavam a ser concebidas pela feitura em uma simples tabua rasa de madeira. Contudo a adulação e a veneração exageradas aos ícones, as decorrentes disputas teológicas entre os bispos acerca da possibilidade e legitimidade de representação de um 
Deus-Uno-Trino indizível, a reprodução da figura de Jesus Cristo excessivamente humana, ou de Maria como a Mãe de Deus, ou dos Santos que testemunharam a fé, despertaram rixas, contraposições, altercações só resolvidas no decorrer do século IX, quando, finalmente, as resoluções do Concílio de Niceia foram colocadas em práticas.

Os ícones a partir então tinham um lugar de predileção do cenário das igrejas com o beneplácito dos hierarcas e imperadores e com a força de legitimação dada pelo Concílio. Sob a iconoclastia, como ficou conhecido o movimento de deposição das imagens sagradas, orbitavam questões agudas acerca da Teologia e da hermenêutica doutrinal, como também acerca de disputas políticas internas. Uma vez repostas nas igrejas como artefatos de uma fé, as imagens sinalizavam o recomeço de um modo propagador de verdades cuja mediação se dava através do intelecto, razão, lógica e também por meio das sensibilidades. A partir do Concílio de Niceia, os ícones passaram também a ser concebidos como artifícios de fronteiras: da ilegalidade à legalidade, da ilicitude à licitude, da desconfiança à legitimidade. Se primeiramente a imagem escrita sobre madeira mais que utilidade ornamental e estética servia para catequização, instrução e doutrinação aos cristãos, após o século IX apresentava-se também como explícito revanchismo sobre aqueles que queriam a defecção das imagens.

Se as imagens no dizer de Deleuze, instituem-se uma ideia em pintura (DELEUZE, 1999), os ícones bizantinos espetacularizavam o convencimento da possibilidade humana de representar as realidades místicas e espirituais através de artefatos materiais. Ademais, a ideia de que todo ser humano está inclinado à transcendência apesar de sua corporeidade - e por isso, torna-se ontologicamente semelhante a Deus- é defendido pela Teologia das Igrejas cristãs Orientais e perpetuado pela feitura de ícones (USPENSKI, 2013). A necessidade de solidificar tal conteúdo de fé impulsionava a que a figura dos ícones bizantinos ratificasse o que a letra já dissera. As imagens cristãs bizantinas chancelavam então, os dizeres e as formulações dogmáticas de um sistema de crenças muito bem arquitetado. $\mathrm{O}$ que as imagens iconográficas deixavam mostrar não era invenção, mas a sanção do que tinha sido deferido nos Concílios Ecumênicos. Logo, na feitura de um ícone, não estava em 
voga somente uma disposição de figuras que primava pela estética; o primordial era veicular pelo conjunto de cenas as verdades anteriormente promulgadas pelos textos escritos.

\section{Iconologia: a historicidade dos ícones bizantinos}

A Teologia Bizantina credenciava os ícones como artefatos prenhes de signos capazes de se chegar a um conhecimento. O ícone demonstrava através de traços, cores, ângulos o teor de resoluções formais acerca da fé instituída; a seu modo, então, anunciava de forma independente da pura escrita, um dizer dogmático, teologizante. Entretanto, em a Sociedade do espetáculo, Guy Debord lança um alerta que ainda serve para o historiador das imagens: elas não substituem o mundo real, pois forjam outros (DEBORD, 1997, p. 18). Se a fé cristã imperializada foi demonstrada também pela invenção de imagens e de signos que mexiam com as sensibilidades de crenças, fazia reverberar um modo social de existir e organizar coletivamente. Contudo, como se instituía também uma forma de arte era emitente de signos de natureza religiosa, mas que repercutia e influenciava na cultura de todo império bizantino. Os ícones expressavam pensamentos e modos sociais da coexistência humana no império que se cria resultante da vontade divina. E a iconografia servindo-se de regras, de formulas, de ordenamentos, de legislação não fugia desse modus vivendi coletivo para compor suas figuras.

$\mathrm{Na}$ perspectiva do cristianismo bizantino, o iconógrafo por excelência é o monge. Ainda sem ser formalizadas, até o século IV, já estavam estabelecidas pela tradição comunal dos mosteiros e celas monásticas as normas da confecção iconográfica cristã oriental. Aos monges consagrados, ficou normatizado que lhes caberia a tarefa da escritura de um ícone, após dias de intenso jejum, leituras bíblicas, orações distribuídas nas diversas horas do dia, desde que aprovado por seu superior hierárquico. Sem pressa, sem compromissos com o tempo, muitos ícones bizantinos foram confeccionados ao longo de anos. Graças a este particular, muito facilmente os apreciadores da 
arte bizantina, por vezes, verificam incongruências de estilos em uma mesma tela iconográfica. Como o ícone não tinha autoria - porque acreditava-se que a inspiração não era humana, mas vinda de Deusmuitas mãos colaboravam na feitura e criação da peça religiosa. Sem compromissos com a tempo e sem reclamar a autoria, a iconografia cristã bizantina era reflexo de temporalidades diferentes, estilos que se entrecruzavam e um caldo de devoções múltiplas, o que para a História torna-se um desafio investigativo.

O monge cristão oriental instituía-se, então, o materializador dos signos, porque emitia através da imagem, no espaço e no tempo, as mensagens teológicas. Empreendia as mãos para conceituar o indizível; reunia tinta e a ajuntava com os dedos os pequenos fragmentos da dedução iconológica para expor verdades de cunho teológico. As mãos do monge, como extensão de um modo de dramatizar a divindade, com perícia sabiam reunir pedaços desconexos do instituído em uma só imagem, criando outra composição de inteligibilidades.

Para exemplificar o dito acima, entre tantas a imagens cristãs bizantinas, abaixo segue o ícone da Dormição da Theotokos porque pareceu condensar as questões aqui levantadas. A junção de pequenos textos bíblicos, tradição e maneira de se observar a morte em uma certa cultura, tempo e contexto social, formou uma ilustração composta, sem confundir a personagem principal. 


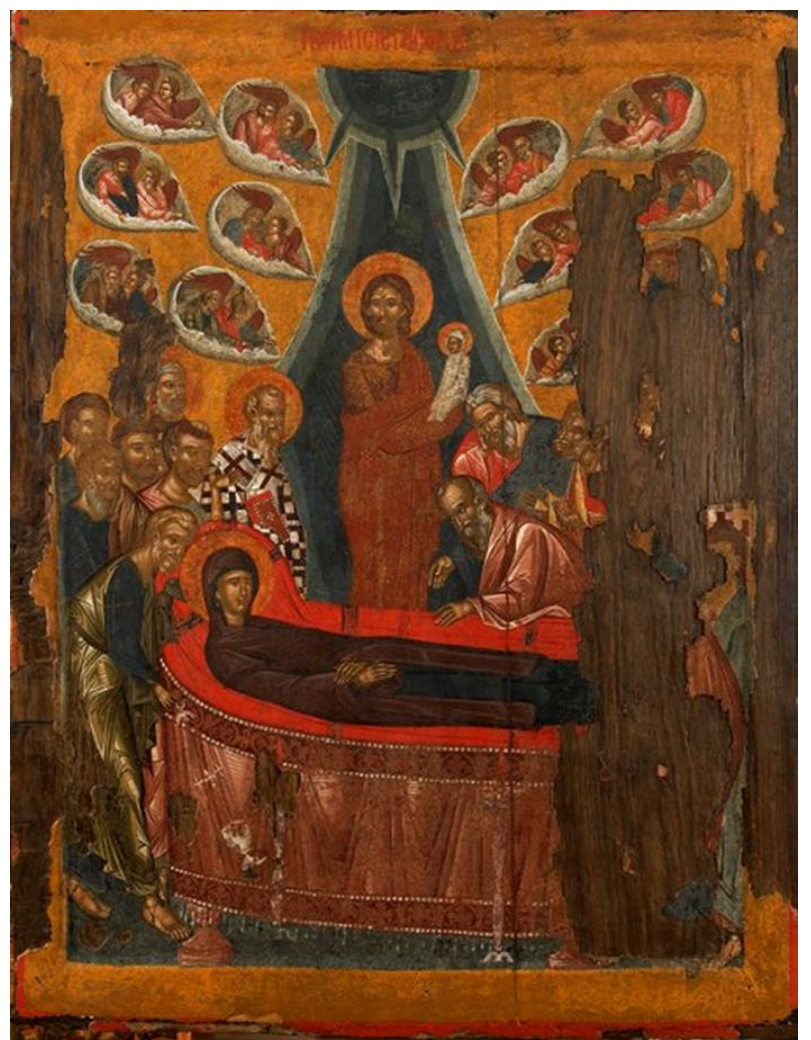

Figura 1 Dormição da Theotokos. Século IX. Grécia. Reprodução.

O ícone acima, pensado para representar o dogma da Dormição de Maria, é um exemplo dessa junção. Na linguagem dos cristãos orientais evitava-se o termo morte, substituído pelo verbo adormecer ou pelo substantivo adormecimento que são vocábulos de origem grega de onde deriva para o português a palavra

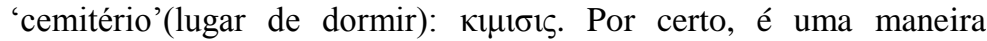
abrandada, menos carregada, de pensar a morte. Nestes termos, a morte era compreendida por um merecido descanso de um corpo que teve história, que deixava suas marcas no tempo e nas memórias dos outros. 
A tradicional representação iconográfica da Dormição de Maria mostra a Virgem estendida em um leito para o último sono, rodeada pelos apóstolos, vindos dos lugares onde pregavam o evangelho, tendo ao centro Jesus Cristo que acolhe a sua alma, representada como uma pequena menina envolta em faixas e por ele sustentada.

Para a composição desse ícone, o monge serviu-se dos textos bíblicos e da tradição apostólica que narravam o apóstolo Tomé, tendo chegado atrasado para o sepultamento da Virgem e querendo rever seu semblante, fez reabrir o túmulo, mas este foi achado vazio. Contudo, a própria Mãe de Deus lhe tinha revelado, numa visão, que havia ressuscitado e subido ao céu junto do seu Filho divino (PASSARELLI, 1997, p. 15). É perceptível que a composição plural das imagens se afunilou em um mosaico iconográfico que abrangia a tradição e os textos bíblicos. Em um só texto visual estavam presentes, o dogma, a tradição oral, o texto bíblico e a inspiração do monge. $\mathrm{O}$ iconógrafo não esqueceu de abordar uma menção do Evangelista Mateus que lembrava ninguém ser merecedor de entrar no Reino dos Céus se não fosse uma criança, conforme expressa o capítulo 19. Aqui, o historiador Manzatto (1994, p. 22) faz perceber que, tanto a Teologia quanto a Iconografia trabalham com a metáfora, com linguagens e símbolos, esses resultantes da hermenêutica de signos que a própria historiografia detecta.

História então, com seus teóricos e abordagens múltiplas, auxilia a observar que a junção desses episódios para além de ser decorrente da destreza manual do iconógrafo, é procedente da influência cultural experimentada em um império pungente e atuante no comércio, força militar e organização eclesiástica. Desse modo, os pensamentos que norteavam um certo viver social se faziam par com a sensibilidade estética que, por sua vez, provocava um novo dizer. A montagem comportou uma outra figura, um novo texto que pode incorporar narrativas mais compostas. Ou melhor, a colagem de episódios reverberou em polinômios de signos. As informações ajuntadas pelo monge serviram então de elementos pré-textuais que davam àquele iconógrafo a desafiadora oportunidade de recondução de um modo de fazer e transmitir os signos emitidos pela imagem. $\mathrm{O}$ conhecimento magisterial presente nos versos bíblicos compostos e retransmitidos pela Igreja serviu de substrato para novas composições 
que não sabia esconder aquele modo de compreensão e apreensão de mundo em movimento.

Contudo, a arte de escrever em imagens um mundo percebido põe desafios e cuidados na feitura de narrativas. Para além das circunstancialidades de tempo e de lugar, devem ser observados os conceitos teológicos, a organização e modos da vida de coorte do Império Bizantino.

\section{Os signos, o Tempo e o Espaço dos Ícones.}

Santo Agostinho informava que o tempo está ligado à memória. Enfatiza também que o gênero humano é o único capaz de conservar os registros do acontecido já que no passado as coisas já não existem, existindo apenas na alma a memória das coisas passadas (AGOSTINHO, 1990). Assim, na História das Imagens, quando se pensa o tempo, fala-se da impressão ou da percepção que a figura e a arte iconográfica em sua inteireza poderiam ter causado em pessoas, em um grupo ou em uma comunidade. O signo e suas derivações só são possíveis dentro de uma escala de tempo e de memória. Parece que o pensamento de Agostinho, partindo de conceitos objetivos, aclarou a realidade subjetiva acerca do termo, oportunizando enxergar no presente o que a História trata. No 'tempo' de Agostinho, os ícones bizantinos atualizam memórias em narrativas imagéticas avivadas por um desejo de fazer reviver as verdades instituídas pela Igreja e pelo império Bizantino. Na reatualização de memórias, também são reatualizados signos dentro de um contexto de temporalidades diferentes.

Tal assentimento vem ao encontro do que afirma Henri Bergson: a existência de dois tempos (BERGSON, 1999). O tempo dos físicos e matemáticos é, segundo o autor, aquele esquemático e espacial, por isso fugidio: é o momento do acontecimento ou da narrativa. Contudo, há o tempo real movido pela sucessão, mudança, continuidade, memória e pela criação. Esse é o tempo que tem a capacidade de modificar, de alterar e de criar situações, de alternar as 
temporalidades. Verifica-se que este é o tempo da contemplação ao ícone, capaz de obstruir barreiras, pular séculos e fazer parecer que a imagem ainda carrega a frescura e o cheiro das tintas recém pinceladas.

Esse é o tempo que se deixa descobrir em sua duração pela perspectiva da subjetividade e do signo. Por certo, tempo da veneração às imagens religiosas, por exemplo, não é o mensurável; é aquele que encontra acolhimento e tem relação com a memória. Sob este aspecto, a História percebe a memória como instrumento que permite estabelecer uma relação entre o signo iconografado com o momento da veneração, religando dois instantes, conjugando compreensibilidades. Se a duração de cada acontecimento está relacionada ao grau de interesse que a memória estabelece com as correlações da vida do presente, a duração do tempo em uma veneração ao ícone, bem mais que um processo natural e pragmático de conhecimento das coisas, expressa a forma de se posicionar frente a uma mensagem religiosa. É possível inferir que, nessa combinação entre tempo e deferência às imagens religiosas busca-se no passado a inteligibilidade daquilo que os signos remetem e, no presente, a forma e maneiras de sua absorção. Quanto mais o fiel ou o admirador dessa expressão de arte sacra se ater aos detalhes do que foi iconografado, mais perene o signo se torna no presente, até porque, o presente dura enquanto se estiver absorto, embebecido pela contemplação.

O espaço para a iconografia é também elemento de textualidade. De acordo com Heidegger (1996), o ambiente físico e os símbolos que o adornam produzem ou "fazem espaços" de copertencimento entre pessoas e o local arquitetônico. Desse modo, a impressão imediata de uma experiência religiosa se dá talvez, por primeiro, no espaço onde se reúnem os fiéis de uma determinada confissão. O autor, comparando a beleza e o estupor provocado por uma obra de arte com o seu lugar de exposição, compreende que tanto ela quanto o lugar ocupado por ela não são duas realidades descompromissadas, mas ligadas por uma necessária co-pertença, que faz e edifica impressões (HEIDEGGER, 1977). Nesse sentido, o lugar de exposição dos ícones bizantinos é também local em que se aliançam impressões e constroem relações capazes de simbolicamente entender e de dar textualidade ao sagrado. Os lugares fazem da textualidade teológica uma beleza a ser admirada porque facilmente 
localizada. Essa beleza é certamente aquela que envolve o fiel por um elemento eterno e invariável, capaz de facilitar um contato, um diálogo com a divindade; tem poder de sacudir e mexer com as impressões, ressignificando os tempos e espaços. Isso posto, pode-se afirmar que os ícones para além de objetos de ornamentação e peças de arte religiosa promovem junção de tempos, aproximação de momentos. Nesse sentido, o filósofo e historiador Walter Rahfeld afirma

[...] não existir nenhuma experiência humana genuína, isolada no tempo e no espaço; o que um povo vivenciou será vivenciado por outras nações em outras épocas e em outras terras, apesar de múltiplas diferenças inclusive de função e acentuação. A vida apresenta traços comuns a todos os homens e um desses traços é a experiência humana. (REHFELD, 1988:38)

Sendo assim, estar em lugar eivado por ícones não pode ser dissociado de uma subjetividade capaz de se comprazer a inteireza de um homem e de uma mulher que procuram sua deificação. Parece que a beleza que desperta a deificação é aquela resultante não só da harmonia de formas, cores e traços bem pontuados, mas quando somada a esse conjunto de condições, vem agasalhada pela soma de totalidades entre lugar e tempo, entre estética e teologia, entre deificação e natureza humana.

\section{A Iconologia e a Iconografia nos olhos do Historiador das imagens}

A Iconologia trata então dos processos e da feitura dos ícones. Estuda os passos e os técnicas manuais de sua escrituração. Isto porque na feitura de toda e qualquer imagem iconográfica gravita 
um contexto teológico, uma cronologia em que se encaixam os fatos, um tempo histórico, sentidos e estéticas. $\mathrm{O}$ caráter informacional da análise depende, é claro, do conhecimento da área de interesse, sob prismas teórico e metodológicos específicos. Logo, para a historiografia não só pela ótica da Arte religiosa ou da Iconografia ou Iconologia objetiva-se compreender os ícones, outros campos de investigação procuram relacioná-los e analisá-los em seus contextos culturais. Em consequência, ampliam-se as possibilidades de descrever o dogmatismo também através das imagens, da arte cênica, da estética majorando possibilidade de olhá-los pela compreensão dos signos que emitem.

A Iconologia procura os passos da Iconografia. Enquanto a primeira não existe sem a segunda, ocupando-se da técnica em saberfazer, a segunda institui-se fonte para a primeira, já que trata dos fundamentos teológicos para a segunda poder existir. Observa-se aqui uma comunhão de funções: uma fala sobre, descreve sobre, a outra se inspira, recebe e decodifica as mensagens do emitente. A iconologia estuda a iconografia e a iconografia sustenta a iconologia em conceitos para dar inteligibilidade e razoabilidade a suas verdades. O iconólogo vê, contempla e fala sobre a obra; o iconógrafo estuda e prepara as imagens, feitas pelas mãos humanas. $\mathrm{O}$ ícone acabado inicia o processo de produção de signos. Se o iconólogo fala sobre o ícone, o iconógrafo fala do ícone e impõe o que se pode dele apreender, sentir, observar, compreender.

Ao Historiador cabe observar o conjunto, a arte toda, a imagem em sua inteireza iconologia e iconografia. Fiando-se pelos meandros da iconologia e iconografia, busca por último o que à ciência historiográfica interessa: a representação orgânica da totalidade da imagem e sua apreensão. Analisa suas complementariedades, miudezas, seus pormenores, quais fontes inusitadas que inspiram deduções, refazem inferências e ditam silogismos. A arte de escrever sobre ícones, sobre imagens religiosas ou a respeito das sensibilidades que se depreendem das imagens está dentro de um processo investigativo de historicidade. Por isso, muitos Historiadores se afastam das abordagens estéticas para se dedicarem às condições de feitura e repercussão de uma imagem religiosa em uma sociedade. Para alguns, a imagem é apenas um resíduo do habitual religioso, para outros significa a segmentação de 
momentos, de instantes encharcados de acepções que fazem do homem e da mulher da contemporaneidade um expectador daquilo que já foram. Por certo a dimensão religiosa é estuda, vasculhada em várias nuances pela Historiografia.

\section{Conclusão}

Durante muito tempo, os historiadores acreditavam que o passado não poderia ser compreendido para fora das fontes escritas oficiais. Tal critério, que perdurou até o século XIX, chegou a determinar que à época em que a escrita não fora dominada, o passado não poderia ser narrado com veracidade e fundamentos lógicos. Contudo, as tendências historiográficas da Escola dos Annales, da História Social inglesa e da Nova História Cultural do século XX influenciaram a produção historiográfica se baseando em formas diversificadas de fontes. Essa renovação colocou em evidência novos temas, novos objetos e novos métodos promovendo uma verdadeira revolução na escrita da História, e, consequentemente, do ensino de História. Desde então, fontes de natureza, visual, oral e sonora foram incorporadas ao conjunto de registros fazendo com que a História observasse seu objeto a partir de recortes multifacetados. Quanto às fontes imagéticas, a historiografia contemporânea verificou que a imagem possuía um registro abrangente, baseado em um dos sentidos que caracterizam a condição humana. Igualmente, muitos historiadores conferiram que se a escrita surgia a partir de um domínio especializado, a leitura e interpretação de imagens acompanharam o saber humano, desde o aparecimento racionalidade, porque a visão vinha antes das palavras.

$\mathrm{Na}$ atual historiografia, as imagens ajuntadas, as figuras em sintaxes, com seus hiatos, sombras e perfilhações filiam-se ao repertório da curiosa e venatória investigação acerca de objetos marginais que, sob o método indiciário de leitura e interpretação de Carlo Ginzburg, são capazes de produzir conhecimento e de oferecer respostas a algumas indagações (GINZBURG, 1989). O 
reconhecimento de novas possibilidades de estudo sobre o uso da imagem na História, por exemplo, coloca a visualidade ou a centralidade do olhar no cerne das interrogações e problemáticas das atuais pesquisas. Logo, na perspectiva da História Cultural é possível fazer pesquisas historiográficas utilizando-se de imagens desde que estas levem a construção de uma leitura dos acontecimentos que valorize o processo contínuo de compreensão do ser humano em um mundo em contínua recomposição cultural. Isto porque as imagens, uma vez sendo suporte de relações sociais, não são apenas efeitos, ou sintomas, mas a própria visualidade como princípio cognitivo de caráter indefectivelmente histórico.

Longe de se narrar curiosidades e mera propagação da arte bizantina, o uso dos ícones na Historiografia busca articular os saberes de uma teologia engendrada por um Império das especificidades do tema, com a crítica de toda e qualquer fonte que se serve as pesquisas. Verifica-se, então, que o uso dos ícones bizantinos na composição de narrativas encerra-se dentro de um contexto da historicidade visual, teológica, filosófica e cultural. Uma vez que as imagens estão sujeitas à polissemia dos sentidos, a História reitera o cuidado de não se cair na armadilha proveniente do estupor ou da mera contemplação de uma arte. É necessário ultrapassar aquilo que esteja aparentemente representado na própria figura e perscrutar os usos e as funções da imagem num contexto plural de conhecimentos. Importante notar que a utilização da imagem no construto de um saber historiográfico não se constitui em oposição às formas outras de narrativas; é uma maneira colaborativa de se construir a História, por outros métodos.

Assim, na perspectiva do estudo da iconografia bizantina interessa à História a interpretação do processo da realidade humana dentro de um contexto de tempo e espaço, pensamentos e organizações, à luz dos teóricos e metodologia que credenciam um saber plausível advindos das imagens. Por isso mesmo, o ícone prenhe de seus signos e abstrações, está sujeito à hermenêutica crítica de cientificidade, não deslocado das lógicas e argumentos fundantes de uma narrativa historiográfica condizente. É necessário então debater a aplicabilidade pictórica na construção da narrativa historiografica, sem deixar-se perder pelos deslumbramentos de 
raciocínios confusos e invasivos provenientes de uma imagem solta em um texto sem qualquer justificativa.

$\mathrm{Na}$ atual Historiografia, a religião e a religiosidade praticadas no Império Bizantino não perderam seu grau de importância e nem desviaram-se do centro das atenções, já que não se pode entender o Império Bizantino sem o imbricamento do sagrado e profano, sem a junção e comunhão do Império com a Igreja, sem a parceria dos sistemas de pensamentos da Filosofia e da Teologia oriental. Afinado por estes alertas, no ofício de escrever sobre aquele tempo, o Historiador do Bizantinismo conclui que o ícone bizantino é um recurso que leva a conhecimentos transdisciplinares. Ao fazer uso das imagens bizantinas na constituição de uma narrativa historiográfica, o historiador instaura os sinais de uma urgência porque observa possibilidades de escuta das imagens e dos gritos do passado, revisita uma organização complexa de grupos sociais separados e subjugados pelo poder humano que se cria divino. E esse hiato não é coberto apenas pelas teorias exclusivas da arte, pela psicologia ou teologia, mas em uma interdisciplinaridade que comunga e colabora pelo surgimento de novas leituras e olhares sobre fontes antigas, já estudadas a exaustão, mas nunca de todo perscrutadas. Por certo, a beleza, a sedução e encantamento da História talvez residam nisso.

O ícone e seus signos remetem a um real já vivido e que, no tempo presente, se prestam à circunspecção e às hermenêuticas de possíveis narrativas. Mesmo sendo realidade iconográfica, signo de verdades instituídas e modos de se pôr em sociedade, as imagens religiosas do Oriente bizantino contemplam um tempo que já se esvaiu e que agora pertencem à História. Assim, os ícones são traços escritos em formas delineadas que anunciam uma profusão de signos, um acúmulo de códigos e uma junção de singularidades materialmente cristalizadas sobre madeira e tinta. $\mathrm{O}$ ícone bizantino intui, reflete, exterioriza o teor de crença, pontifica princípios religiosos e regras sociais e que se abrem à estranheza da História. Por sua vez, a História com seus métodos e aportes teóricos observa os ícones bizantinos a partir da análise de experiência de vida demonstrado na cultura, na sociedade e na conjuntura de um império legitimado por um tempo. Por serem textos se servem da hermenêutica para serem compreendidos em sua razão. 
O ícone bizantino é figura, é imagem e reflexo de um passado, e ao mesmo tempo, discurso de um presente. Se é texto e narrativa, legitimados por concordâncias daqueles que compunham a Igreja cristã até o século IX, no tempo presente institui-se fonte, inspiração e desafio para os pesquisadores. Se foram usados como estandartes de vitória sobre os iconoclastas, hoje, os ícones bizantinos ainda informam a complexidade do ser humano em suas diversas sociabilidades. Através de dogmas estilizados em cores, linhas, abstrações e intuições, comunicam signos e a falta de completude de quem os interpreta. Por isso a fonte imagética para a Historiografia é sempre lida em uma compleição robustecida pela interdisciplinaridade. Uma imagem bizantina nunca está solta, porque com ela comparecem elementos, contextos, circunstâncias, promulgações, dogmas e decretos imperiais, tão caros aos investigadores do Medievo.

Referências

AGOSTINHO. Confissões. Lisboa: Apostolado da Imprensa, 1990.

BERGSON, Henri. Matéria e Memória: ensaio sobre a relação do corpo com o espírito. São Paulo: Martins Fontes, 1999.

CERTEAU, Michel de. A Invenção do Cotidiano. Artes de fazer. 13 ed. Petrópolis: Vozes, 2007.

DEBORD, Guy. A sociedade do espetáculo. Rio de Janeiro, Contraponto, 1997.

DELEUZE, Gilles. Proust e os signos. Rio de Janeiro: Forense Universitária, 2003.

DELEUZE, Gilles. O ato de criação. São Paulo. Folha de São Paulo, 1999.

DERRIDA, Jacques. Pensar em não ver: escritos sobre as artes do visível. Florianópolis: Editora da UFSC, 2012. 
GINZBURG, Carlo. Mitos, emblemas e sinais: morfologia e história. São Paulo: Companhia das Letras, 1989.

HEIDEGGER, Martin. A origem da obra de arte. Lisboa: Edições 70, 1977.

HEIDEGGER, Martin. L'art et l'espace. In: Questions III-IV. Paris: Gallimard, 1996.

SAID, Edward W. Orientalismo: o Oriente como invenção do Ocidente. São Paulo: Cia. das Letras, 2007.

HEGEL, G. W. F. A razão na história: introdução à filosofia da história universal. Lisboa: Edições 70, 1995.

MANZATTO, Antônio. Teologia e literatura. Reflexão teológica a partir da antropologia contida nos romances de Jorge Amado. São Paulo. Edições Loyola, 1994.

PASSARELli, Gaetano. O Ícone da Dormição da Mãe de Deus. São Paulo: Ave-Maria, 1997.

REHFELD, Walter. Tempo e religião: a experiência do homem bíblico. São Paulo: Perspectiva, 1988.

RIBICHINI, Sérgio. Sulle tracce del mito. Dei ed eroi greci, tra archeologia e storia delle religioni. IN.: Archeo, n. 226, Abril 2007 . Roma, Itália.

USPENSKI, Leonid. Teología del ícone. Salamanca: Ediciones Sígueme, 2013.

RECEBIDO EM: 15/04/2016 APROVADO EM: 29/11/2016 